\title{
UPUPIANIE HENRYKA, CZYLI NEKROŠIUS INSCENIZUJE GOMBROWICZA
}

JACEK KOPCIŃSKI

\author{
Instytut Badań Literackich PAN \\ The Institute of the Literary Researches \\ of the Polish Academy of Sciences \\ jacekkopcinski@o2.pl
}

Związki dramatu i teatru są bliskie, ale burzliwe, i właściwie zawsze polegają na zdradzie, która na szczęście bywa twórcza. Wierność (autorowi, tekstowi) w teatrze nie istnieje, współczesna inscenizacja dramatu stanowi przecież taki rodzaj intersemiotycznego przekładu znaków językowych na materialne, w którym konkretyzuje się i unaocznia sens inscenizowanego dzieła, a nie tylko kształt przedstawionego w nim świata. „W tekście dramatu nie zapisuje się «materii» znaków teatralnych, lecz ich znaczenia: np. znaczenia gestów wykonywanych na scenie, nie zaś same gesty. Co więcej, nie jest powiedziane, czy to znaczenie ma być przekazane gestem, czy np. dźwiękiem. Współczesna inscenizacja teatralna pozwala zauważyć, jak odmiennie realizuje się w różnych wersjach scenicznych ten sam tekst" - pisze Jolanta Brach, główny akcent kładąc na prawo reżysera do wyboru własnych środków scenicznych w interpretacji dramatu1. Oglądając Matkę w reżyserii Jerzego Jarockiego z Ewą Lassek w roli tytułowej (Stary Teatr 1964, wersja telewizyjna 1976) czy Wyzwolenie w reżyserii Konrada Swinarskiego z Jerzym Trelą w roli Konrada (Stary Teatr 1974), można powiedzieć, że ci wybitni artyści nie tyle dramat inscenizowali, ile go na nowo pisali - głosem i ciałem aktorów, światłem, scenografią, rekwizytem, muzyką i dźwiękiem. Właśnie z tego powodu w ich spektaklach kształt akcji scenicznej niekiedy znacznie się różnił od kształtu akcji dramatycznej, zarówno na poziomie bezpośrednich przedstawień (osób, działań, zdarzeń, sytuacji, okoliczności,

1 J. Brach, O znakach literackich i znakach teatralnych, [w:] Problemy teorii dramatu i teatru, red. J. Degler, Wrocław 1988, s. 183. 
miejsc), jak i stylu czy tonacji całego utworu, o której decyduje najmniejszy gest, podniesione brwi czy łza w oczach aktora.

We współczesnym teatrze to nic wyjątkowego. Przeciwnie, interpretacja dramatu poprzez reżyserię komplementarnych wobec tekstu działań scenicznych (a także sekwencji muzycznych czy filmowych projekcji itp.) od lat stanowi powszechną praktykę, decydującą o sposobie pracy nad dziełem literackim, ekspresji znaczeń, wreszcie komunikacji z widzami. Fortunność takiego dialogu z jednej strony zależy od talentu i inteligencji reżysera, z drugiej zaś - od dyspozycji odbiorców, nie zawsze gotowych na proponowaną przez inscenizatora interpretację. Ukazując to, jak rozumie i odczuwa dramat, a nie to, jak wyglądają poszczególne postacie, jak mówią, poruszają się i budują interakcje w określonym czasie i przestrzeni, reżyser siłą rzeczy podważa nasze odbiorcze przyzwyczajenia. Uaktywniają się one nie tyle w trakcie lektury czy spektaklu, ile dużo później - kiedy zmienia się kontekst społeczny czy kulturowy dramatu, a jego dawna egzegeza czy inscenizacja nadal funkcjonuje, i choć coraz słabiej kontaktuje nas z danym utworem, sama w sobie podlega pewnego rodzaju „kanonizacji”. Stereotypy, które kiedyś były żywą interpretacją, w nowej sytuacji otaczają dzieło myślowym kokonem i bronią do niego dostępu. Dlatego zjawienie się reżysera, który gotowy jest zerwać tę jałową otulinę, to dla dramatu i jego odbiorców moment szczęśliwy, choć zarazem trudny. Stereotypy nie tylko bowiem utrwalają określony sposób rozumienia dzieła, ale także zaświadczają o jego randze i wartości. W odczuciu widzów nowa interpretacja może je osłabiać, a nawet niszczyć, i właśnie z tego powodu bywa odrzucana. Co ciekawe, gest tego rodzaju odmowy często wykonują recenzenci teatralni, a więc widzowie o specjalnych kompetencjach, teoretycznie najlepiej przygotowani na intelektualną „współpracę” z reżyserem. Dezynwoltura niektórych współczesnych inscenizatorów, którzy dekonstrukcję dzieła przedkładają nad jego interpretację, do pewnego stopnia tłumaczy konserwatyzm części krytyki. W przypadku inscenizacji drążących, a nie burzących sensy dramatu jest on jednak niezrozumiały i zdradza raczej umysłowe lenistwo niż szacunek dla autora.

Nie zamierzam dłużej teoretyzować na temat twórczej (reżyserskiej) i zupełnie nietwórczej (recenzenckiej) zdrady w teatrze. Przedstawię natomiast przypadek zdrady konkretnej, w którą uwikłani są: wielki polski dramatopisarz - Witold Gombrowicz; wybitny, zmarły niedawno reżyser 
z Litwy - Eimuntas Nekrošius; i znany krytyk współczesny - Jacek Wakar. Sprawa między nimi rozegrała się w Teatrze Narodowym późną wiosną roku 2018, a pikanterii dodaje jej fakt, że pisarza, inscenizatora i recenzenta połączył... Ślub ${ }^{2}$.

W II akcie Ślubu słowo „zdrada” pada aż dziesięć razy. Cztery razy słychać słowo „zdrajca”, raz „zdrajcy”, raz „zdradzić”. Pojawia się też postać DOSTOJNIKA-ZDRAJCY i zbiorowy bohater nazwany ZDRAJCY. Gombrowicz, odkąd uciekł ze statku, który z Buenos Aires miał go zawieźć do Europy ${ }^{3}$, a potem „zniknął z oczu kolonii” polskiej, werbującej młodzież do wojska ${ }^{4}$, sam owładnięty obsesją zdrady, w Ślubie zaszczepia ją Ojcu i Henrykowi. Ojciec pasował się na króla, a teraz, jak każdy monarcha, wszystkich podejrzewa o zdradę, zwłaszcza Dworzan i Dygnitarzy, w których przedzierzgnęli się niechętni mu Pijacy.

OJCIEC

Tsss... Hendryś, tylko ty mnie nie zdradź, bo tu nie brak zdrajców... Nie wystaw mnie na pośmiewisko, Hendryk... bo tu zdrada... zdrada... zdrada... Zdrada! (oddala się, wstępuje na podwyższenie) ${ }^{5}$.

Henryk, oczywiście, zdradzi Ojca i odbierze mu koronę, by stać się też kapłanem, a nawet Bogiem i sobie samemu udzielić ślubu. Do ceremonii jednak nie dochodzi, bo także on poczuje się zdradzony przez swego przyjaciela Władzia i, oczywiście, Manię, która - jak zapewnią Henryka jego rodzice z młodszymi się „krwawiła”. Słowo „zdradzać” w języku Henryka oznacza „nie dotrzymać danego słowa”, „postąpić wbrew obietnicy lub przysiędze”, ale także „wydać” (komuś kogoś lub coś) i „ujawnić” czy „wyjawić” (komuś coś). Ten ostatni przypadek jest w Ślubie szczególnie ważny, bo czasownik „zdradzić” w tym właśnie sensie funkcjonuje też w trybie zwrotnym - można „zdradzić się", np. słowem czy gestem, czyli wbrew woli wyjawić jakąś wiedzę

2 Premiera odbyła się 15 czerwca 2018 roku.

3 K. Suchanow, Gombrowicz. Ja, Geniusz, Wołowiec 2017, s. 385.

4 W. Gombrowicz, Kronos, Kraków 2013, s. 69.

5 W. Gombrowicz, Ślub, [w:] idem, Dramaty, Kraków 2012, s. 154. 
lub ujawnić jakąś cechę czy skłonność. W formie rzeczownikowej zdrada jest synonimem kłamstwa, oszustwa, udawania, pozoru oraz niewierności. W tym ostatnim znaczeniu liczą się zarówno konotacje erotyczno-obyczajowe, jak i polityczno-wojskowe. Gombrowicz aktualizuje obie, samemu słowu „zdrada” nadając chętnie znaczenie metaforyczne, jak w tej znanej kwestii Henryka, która brzmi jak wykład z filozofii języka:

\section{HENRYK}

A zatem wszystko to kłamstwo! Każdy mówi

Nie to co chce powiedzieć, lecz to co wypada. Słowa

Zdradziecko łączą się za plecami

I to nie my mówimy słowa, lecz słowa nas mówią

Zdradzając naszą myśl, która też zdradza

Nasze zdradzieckie uczucie, ach, ach, zdrada!

(pijany) Nieustająca zdrada! ${ }^{6}$

Według bohatera Ślubu, w słownych interakcjach silniejsza od ludzkiej woli jest konwencjonalna forma, która mówiącym odbiera podmiotowość i używa ich do własnych celów (jak gauczowskie noże w opowiadaniu Borgesa, którego polski pisarz poznał w Argentynie). Gombrowicz personifikuje słowa, czyniąc z nich dramatycznego antagonistę, skonfliktowanego $\mathrm{z}$ innymi personifikacjami: myśli i uczuć, a więc duchowych władz człowieka. Między nimi toczy się podstępna walka, która polega na „niewierności” i jest znakiem wewnętrznej dezintegracji. Mówimy jedno, myślimy drugie, a czujemy trzecie... Gombrowicz zaznacza, że Henryk, wypowiadając tę myśl, jest „pijany”, choć jego bohater tylko słyszy nazwy trunków, ale ich nie spożywa. „Burgund, burgund” - woła Pijak. „Tokaj, tokaj” - wtóruje mu Zdrajca. Henryk „,upija” się abstrakcyjnie, podpuszczany przez Pijaka, który, zanim nakłoni go do obalenia Ojca, zalewa bohatera wątpliwościami.

\section{HENRYK}

A ja w tym tonę, tonę... Jak pijak

Jak pijak niezupełnie stoję, w głowie mi się troi

Nieswojo słyszę i niepewnie widzę

${ }^{6}$ Ibidem, s. 185. 
I niby to rozumiem, ale nie rozumiem... Szum. Szum.

Bum, bum!

Jak w tej sytuacji wierzyć w jego deklaracje? Jak ufać jego słowom? Przecież Henryk, w myśl głoszonej przez siebie koncepcji, jest zupełnie niewiarygodny! Naprawdę mówi jak człowiek zamroczony alkoholem albo jak dziecko, które łatwo się rozprasza; mówi bez sensu, ulega czarowi onomatopei, udaje:

\section{HENRYK}

Wiem, że nie jestem naprawdę królem.

A jednak czuję się królem.

Co chwila bawię się jak dziecko.

Oczywiście, pragnie, byśmy mu wierzyli, a kiedy zdradzi Ojca, zrobi wszystko, by „zapanować” nad zdradzieckimi uczuciami, myślami i słowami innych bohaterów. Pomogą mu w tym inteligencja, podstęp oraz nóż, który wręczy Władziowi, polecając mu, by się zabił. Ale kiedy chłopak popełni samobójstwo, a oczy wszystkich zwrócą się na niego, znowu zacznie dokazywać, tym razem ze strachu:

\section{HENRYK}

Oświadczam, że jestem niewinny, jak dziecko, ja nic nie zrobiłem, o niczym nie wiem ${ }^{9}$.

Jan Błoński dostrzegał w postaci Henryka bohatera tragicznego, zaznaczając jednak, że tragedia w Ślubie ma tylko wymiar psychoanalityczny: „Ślub na pewno powstał we współpracy z profesorem Freudem"10 - stwierdził krytyk. O tym, jak postępuje bohater, nie decydują przecież bogowie, ani nawet ludzie, ale ukryte pragnienia Henryka, społecznie niedozwolone

7 Ibidem, s. 184.

8 Ibidem, s. 223.

9 Ibidem, s. 252.

10 J. Błoński, „Ślub” jako tragedia psychoanalityczna, [w:] idem, Forma, śmiech i rzeczy ostateczne. Studia o Gombrowiczu, Kraków 1994, s. 116. 
i dlatego zepchnięte do jego podświadomości. Według Błońskiego akcja Ślubu stanowi „podziemną wędrówkę pożądania”, która realizuje się w formie konfliktu dramatycznego spersonifikowanych władz wewnętrznych bohatera. Ze swoich „świńskich” pragnień Henryk lepi sobowtóra, czyli Pijaka - „plugawy cień” społecznej persony bohatera. Uwalniając Pijaka, Henryk spełnia swoje „ciemne” pragnienie erotyczne, a mianowicie czyni z narzeczonej dziwkę, którą następnie zapragnie „oczyścici" i wziąć za żonę. Taki to konflikt tragiczny przeżywa... Tym samym Pijakiem zaatakuje też Ojca, który w dramacie reprezentuje „normę społeczną”. Gdy Ojciec zostaje zaaresztowany i pobity, norma praktycznie znika, co pozwala Henrykowi złamać największy zakaz i nakłonić Władzia do samobójstwa. W planie klasycznej tragedii śmierć Władzia byłaby karą za zdradę, której dopuścił się on wobec Henryka, romansując z Manią. Ale w planie tragedii psychoanalitycznej jest tylko pysznym zaspokojeniem popędu (Błoński powie o „hybris namiętności”); perwersyjnym, bo zapośredniczonym. Henryk nie posiądzie Mani, ani też nie zabije Władzia, co pozwoli mu uchylić się od odpowiedzialności. Mimo że w finale Ślubu spod ławki wypada prawdziwy trup, bohater ucieka w fikcję dziecięcej zabawy, a sposób, w jaki to czyni, „zdradza” jego świadomie rozbudzaną niedojrzałość.

„Wzorem był mi Faust i Hamlet, ale jako format jedynie; mnie szło o napisanie "wielkiego" i "genialnego « dramatu..." - napisał niezbyt skromnie Gombrowicz, ale trzeba mu przyznać rację̧. Ślub jest dramatem wielkim, porównywalnym z dziełami Goethego i Szekspira, a najbardziej genialna wydaje się w nim kreacja głównego bohatera jako postaci nie tylko sprzecznej wewnętrznie, ale jakby z siebie samej wyobcowanej, a zarazem świadomej alienującej ją gry, którą sama inicjuje. Henryk jest jednocześnie słaby i silny, bierny i aktywny, dziecinny i dorosły; stale ulega swoim pożądaniom, a zarazem rozbudza je w sobie, wyodrębnia i wykorzystuje przeciwko innym ludziom. Jest przy tym dość przebiegły, bo atakując, potrafi przedstawić siebie jako ofiarę. Więcej, w odbiorcach swoich niezwykłych, wypowiadanych

${ }_{11}$ W. Gombrowicz, Testament. Rozmowy z Dominikiem de Roux, tłum. I. Kania, Kraków 2012, s. 82. 
na stronie monologów, potrafi znaleźć zrozumienie, a nawet współczucie. Bohater Ślubu w taki sposób umie przedstawić swoją skomplikowaną sytuację wewnętrzną, że gotowi jesteśmy we wszystkim przyznać mu rację i w konsekwencji odpuścić mu wszystkie winy, jako i on odpuszcza je sobie... Czy nie dlatego, że chcielibyśmy zrobić dokładnie to, co on - złamać normy i zaspokoić swoje popędy, a przy tym za nic nie odpowiadać, skutecznie się usprawiedliwić, a nawet poczuć prawdziwą ofiarą i wzruszyć się sobą do łez?

I, oczywiście, objaśniać siebie w sposób tak samo przenikliwy, nadający naszym psychicznym przygodom głębię duchowego doświadczenia. Powodowany pożądaniem Henryk jest przecież filozoficznym alter ego samego Gombrowicza, który w komentarzu do dramatu używał pojęć przejętych z dyskursu egzystencjalistów: „W Ślubie dają się dostrzec mechanizmy nowoczesnego stawania się człowieka i ludzkości"12. Jednocześnie nadawał dramatowi Henryka rangę osobistego doświadczenia rozpaczy, które opisywał jednak z ironią, dziwiąc się swojej językowej sprawności - dokładnie tak, jak swoją klęskę powinien komunikować pisarz nowoczesny:

Zdarzyło mi się wtedy, gdym pisał:

WŁADZIO

Nic.

HENRYK

Nic.

OJCIEC

Przeinaczone.

MATKA

Wykręcone.

WŁADZIO

HENRYK

Zrujnowane.

Wypaczone.

...że rozpłakałem się nagle, jak dziecko - jedyny to raz zdarzyło mi się coś podobnego - nerwy, oczywiście ${ }^{13}$.

Gombrowicz, przepraszam - Henryk, do tego stopnia jest dla nas pociągający w swoim przerażeniu „wewnętrzną składnością nieszczęścia”, że gdy

12 Ibidem, s. 87.

13 Ibidem, s. 83. 
pojawia się interpretator, który próbuje zdemaskować jego grę, a zwłaszcza obniżyć jej rangę - na przykład powiedzieć, że w położeniu tego człowieka nie ma pierwiastka tragicznego, natomiast jest komiczny - natychmiast odzywają się głosy sprzeciwu. Dzieje się tak zwłaszcza wtedy, gdy takim interpretatorem jest reżyser teatralny, na dodatek zagraniczny.

Po premierze Ślubu w reżyserii Eimuntasa Nekrošiusa w Teatrze Narodowym w Warszawie Jacek Wakar, znany recenzent teatralny, napisał:

Wszystko zdawało się oczywiste - jeden z ostatnich teatralnych wizjonerów bierze tekst zagadkowy i porywający, gdy idzie o utwory pisane po polsku, do postawienia w tym samym szeregu, co Dziady, potem Wesele i Wyzwolenie Wyspiańskiego. Po arcydziele Mickiewicza mierzy się z dramatem tej samej rangi, o podobnym pułapie trudności. A przy tym może Ślubem zamknąć dyptyk z Teatru Narodowego, przecież Gombrowicz podejmuje tu romantyczny mit, przenicowuje go, sprawdza, co z niego pozostało. Henryk bywa jak Konrad, gdy staje się kapłanem kościoła ludzkiego. I trudno przy tym znaleźć materiał dla teatru bardziej od Ślubu inspirujący, przy swej wewnętrznej żelaznej precyzji podatny na różnorodne interpretacje. Dało nam takie wielu twórców - w swej kanonicznej krakowskiej wersji sprzed ponad ćwierćwiecza Jerzy Jarocki, potem w Teatrze Narodowym Jerzy Grzegorzewski, ostatnio pracująca z aktorami ze Szczecina i z Opola Anna Augustynowicz. Ślub Nekrošiusa miał im dorównać lub je przebić. Byliśmy tego pewni...

Nie wyszło przede wszystkim dlatego, że - tak podejrzewam - Eimuntas Nekrošius Ślubu nie rozumie, za nic ma rządzące nim zasady ${ }^{14}$.

Niestety, Jacek Wakar zasad tych w swojej recenzji nie prezentuje, stwierdza jedynie, zresztą niezgodnie z prawdą, że litewski reżyser pominął w swojej inscenizacji motyw wojny oraz nie zmierzył się $\mathrm{z}$ koronnym dla Gombrowicza problemem formy. W spektaklu Nekrosiusa słusznie dostrzega „dziwny taniec” wydrążonych marionetek, "galopadę min,

14 J. Wakar, Pustka marionetek, https://kultura.onet.pl/teatr/pustka-marionetek-slub-witolda-gombrowicza-rez-eimuntas-nekrosius-teatr-narodowy-w-recenzja/36q077c [dostęp: 4.12.2018]. 
dziwacznych kroków i grymasów", nie zadając sobie jednak trudu zrozumienia przyczyny, dla której Nekrošius właśnie w taki sposób ukazał świat bohaterów dramatu Gombrowicza.

Najciekawsza w jego wypowiedzi jest jednak retoryka. Krytyk najpierw zaświadcza o najwyższej randze Ślubu, żeby potem autorytatywnie stwierdzić, że inscenizacja litewskiego reżysera do niej nie dosięga. Na celownik bierze przede wszystkim odtwórcę roli Henryka: „Kiedy przyzwyczaimy się do marionetkowej konwencji [spektaklu - przyp. J.K.], zostaje ona porzucona i przez chwilę grają Ślub jak Ślub. Tyle że wtedy widać, że przedstawienie nie ma najważniejszego bohatera, gdyż Mateusz Rusin jako Henryk wygląda na błąd obsadowy. Jest płaski, bezradny, może to jeszcze za wysokie progi dla młodego, utalentowanego aktora". W przekonaniu recenzenta zbyt młody aktor gra Henryka źle, ponieważ jego bohater jest jednowymiarowy i nieskuteczny w działaniu. Nie dopuszcza do siebie myśli, że „płaskość” i „bezradność” bohatera mogą być w jego kreacji zamierzone, że - pójdźmy o krok dalej - reżyser dramatu nie odnalazł w Henryku wielowymiarowości, a jego skomplikowane intrygi i gry uznał za porażkę postaci bardziej śmiesznej niż tragicznej. Wakar wolał przyjąć, że podziwiany przez niego reżyser „Ślubu nie rozumie”, niż że rozumie go inaczej niż przewiduje to kanon ustanowiony przez Jarockiego w jego inscenizacji w Starym Teatrze w Krakowie z 1991 roku z Jerzym Radziwiłowiczem w roli Henryka - kongenialnej wobec dramatu Henryka także pod względem absolutnego zaufania reżysera do interpretacji, którą podsunął sam Gombrowicz, i poważnej, wręcz katastroficznej tonacji dzieła.

Tymczasem Nekrošius nie był głupcem, ale zdrajcą... Doskonale rozumiał Ślub, ale nie uległ perswazji interpretacyjnej jego autora. Zdrada Nekrosiuša była dla wyznawców Gombrowicza dotkliwa, ponieważ swoją inscenizacją podważył on wymowę jego największej sztuki, paradoksalnie dochowując wierności literze tekstu. Zachował przecież kompozycję dramatu, nie wprowadził do scenariusza spektaklu wypowiedzi pochodzących z innych dzieł, a nieznaczne skróty, które można wyśledzić, nie zmieniły znaczenia warstwy dialogowej Ślubu. Natomiast na poziomie znaków scenicznych, 
które w spektaklu powstają w wyniku skomplikowanego przekładu ${ }^{15}$, dzieło Nekrošiusa jest pełne niespodzianek. Szczególnie zaskakująca jest obsada przedstawienia, a zwłaszcza wygląd, charakter i pozycja poszczególnych postaci, których działania względem ich dramatycznych pierwowzorów mają charakter metaforyczny.

W spektaklu uderza przede wszystkim odmienna niż w utworze Gombrowicza relacja między Henrykiem i jego rodzicami, decydująca o ich tożsamości, sile i charakterze. Matka i Ojciec (w ich rolach Danuta Stenka i Jerzy Radziwiłowicz) zjawiają się na scenie jako pierwsi, by rozegrać między sobą małą slapstickową etiudę (niczym ze znanego dramatu Becketta), poprzedzającą właściwą akcję Ślubu. Bawiąc się słowami zapisanymi na niewielkich tabliczkach (jedna z nich zawiera wezwanie: „Nie zdradzaj”), budują między sobą zagadkowy i niepewny świat, do którego nagle wkracza Henryk. To nie syn śni w tym spektaklu rodziców, by następnie nimi manipulować - to rodzice wabią syna, który, gdy tylko wpada do ich świata, zaczyna realizować jakby z góry założony scenariusz. W spektaklu Nekrošiusa rodzice są zdecydowani, silni i przebiegli, współpracują ze sobą niczym partnerzy podczas akcji wojskowej (oboje początkowo noszą kostiumy przypominające mundur, a więc ubrani są tak, jak w dramacie Gombrowicza Henryk i Władzio). Natomiast ich syn jest słaby i dość nieporadny, co grający go aktor manifestuje kostiumem i sposobem poruszania się (nosi na sobie szare trykoty gimnastyczne, kojarzące się ze szkolną lekcją WF-u; w miarę upływającego czasu pojawiają się na nich plamy potu). Wypowiadając swoje kwestie, Henryk wykonuje też szereg gestów, które budzą skojarzenie z dziecięcą zabawą. W pierwszym akcie chowa się pod stołem i właśnie tam obmyśla plan „zapanowania” nad sytuacją, która go zaskoczyła.

Czy decyzja reżyserska, by właśnie tak ukształtować postać Henryka, znajduje w tekście dramatu jakiekolwiek uzasadnienie? Owszem. Pytanie jednak, czy zgodzimy się na zastosowaną przez Nekrošiusa metodę interpretacji dramatu, na którą składa się kilka charakterystycznych czynności.

15 Tadeusz Kowzan wymienia ich aż trzynaście: słowo, intonację, mimikę, gest, ruch sceniczny, charakteryzację, fryzurę, kostium, rekwizyt, dekorację, oświetlenie, muzykę, efekt dźwiękowy. Zob. T. Kowzan, Znak w teatrze, [w:] Problemy teorii dramatu i teatru, red. J. Degler, Wrocław 1988, s. 370. 
Pierwsza wiąże się z bardzo uważną lekturą tekstu i polega na wyodrębnieniu w nim tych pojęć, figur, obrazów i motywów fabularnych, które w reżyserskim odbiorze okazały się kluczowe dla zrozumienia całości utworu. Nie jest to wybór kompletny ani obiektywny; przeciwnie, reżyser, jak każdy interpretator, skupia się tylko na niektórych elementach dzieła - tych, które szczególnie go poruszyły i zainteresowały. Jest to więc wybór do pewnego stopnia arbitralny, oparty jednak na autorytecie, którym artystę obdarzają widzowie czy też, ujmując rzecz nieco szerzej, wspólnota odbiorców, z zaufaniem oczekujących od artysty teatru autorskiej interpretacji dramatu uznanego za ważny za sprawą jego wcześniejszych odczytań i inscenizacji, a także innych działań i okoliczności „kanonizacyjnych”, jak choćby wprowadzenie do podręczników czy zestawu lektur akademickich. Liczą się tu zarówno doświadczenie artysty, jego wiedza i wyobraźnia, jak i sytuacja zewnętrzna - społeczna, polityczna, kulturowa - której kształt może mieć wpływ na sposób interpretacji dramatu i wymowę powstającego spektaklu. W przypadku Ślubu w reżyserii Nekrošiusa nie wolno lekceważyć tego aspektu pracy reżysera, mimo iż nie był on artystą stale w Polsce obecnym.

Na jego interpretację dramatu Gombrowicza znaczny wpływ miała także reżyserska lektura innych dzieł pisarza, w szczególności napisanej wcześniej Ferdydurke i opublikowanego równolegle ze Ślubem argentyńskiego Trans-Atlantyka. Poświadczają one celność i nieprzypadkowość reżyserskiego wyboru kluczowych elementów dramatu i wpływają na sposób rozumienia treści, które przykuły jego uwagę. Krok następny to szukanie adekwatnych i sugestywnych znaków scenicznych dla ich wyrażenia, utrzymanych w konwencji pociągającej reżysera, ale i atrakcyjnej dla widzów, którzy w Teatrze Narodowym od dwóch lat mogli uczyć się języka teatru litewskiego reżysera na Dziadach Adama Mickiewicza. Tak jak w tamtym spektaklu, także w Ślubie aktorzy wypowiadają kwestie swoich postaci, uczestnicząc w skomplikowanych działaniach równoległych wobec tekstu, powiązanych z nim jedynie na zasadzie metaforycznej amplifikacji wybranych elementów semantycznych dzieła. Widz staje więc przed bardzo trudnym zadaniem podążając za sensem skomplikowanych wypowiedzi bohaterów Ślubu, musi domyślać się znaczenia zaskakujących sytuacji scenicznych, wyprowadzonych przecież nie z didaskaliów utworu, ale z tekstu głównego, poddanego autorskiej interpretacji. Taka konstrukcja spektaklu może nie zostać przez odbiorcę zaakceptowana, ważne jednak, by została zrozumiana, czego 
nie można powiedzieć o cytowanym powyżej recenzencie przedstawienia w Teatrze Narodowym.

W jaki sposób litewski reżyser zinterpretował Ślub? Po pierwsze, bardzo poważnie potraktował te kwestie Henryka, w których dorosły bohater (tak jak dorosły pisarz) porównuje się do dziecka. Jak już wiemy, bohater robi to w kluczowych momentach swojej intrygi (a pisarz w kluczowych momentach cytowanej autointerpretacji Ślubu). Mówiąc „bawię się jak dziecko” i „jestem niewinny, jak dziecko", podważa realny wymiar swojego postępowania i oddala od siebie odpowiedzialność za położenie ludzi od niego zależnych. Oczywiście, traktuje te słowa jako sprytną wymówkę, ale czy nie zdradzają one jego infantylnej świadomości? Świadomości człowieka, który podlegając tyranii pożądania, stracił realny kontakt z rzeczywistością i już niczego nie może być pewny - ani uczuć, ani myśli, ani słów, których tak wiele w dramacie wypowiada? Czy porównując się do dziecka, Henryk nie „zdradza”, w sensie: ujawnia, swojej niedojrzałości, którą w istocie do końca celebruje?

Jeśli zgodzimy się z taką interpretacją, nie zaskoczą nas działania sceniczne Mateusza Rusina w roli głównego bohatera, które przypominają czynności dziecka o autystycznej osobowości, podlegającego stałej kontroli rodziców. Powstaje niezwykłe wrażenie - słowa i myśli Henryka, które w dramacie gotowi jesteśmy uznać za wyraz jego samodzielności, w spektaklu odbieramy jak rolę, którą pozwalają mu zagrać rodzice na ustanawianych przez siebie warunkach i dla podtrzymania pozorów emancypacji syna. Koronnym dowodem takiego postępowania jest maskarada, jaką urządza Matka, udając przed Henrykiem jego dawną narzeczoną Mańkę. Recenzenci Ślubu uznali, że Danuta Stenka gra w tym spektaklu dwie postacie, tymczasem jest inaczej, Stenka gra tylko Matkę, która udaje przed Henrykiem Mańkę, jakby świadomie blokując proces jego dojrzewania. Narzuca się skojarzenie z Ferdydurke, i rzeczywiście - Henryk zostaje przez rodziców „upupiony” i skazany na wieczną niedojrzałość. Nie buntuje się naprawdę, a jedynie gra swój bunt, bo tylko na to powalają Matka z Ojcem, do końca traktujący go jak „dziecko specjalnej troski”. W zderzeniu z męskimi pragnieniami i aspiracjami sytuacja ta rodzi w bohaterze coraz większą, wręcz 
chorobliwą, frustrację chłopczyka, który nie może wyzwolić się spod dominacji rodziców.

Problem w tym, że to sam Henryk odpowiada za ten stan rzeczy, wie bowiem dobrze, że tylko jako dziecko może sobie pozwolić na bezkarne przekroczenia motywowane pożądaniem. Cierpi z powodu kontrolujących go rodziców, ale też stale ich potrzebuje, by pozwalać sobie na więcej i więcej. $\mathrm{W}$ gruncie rzeczy to on sam stwarza swoich tyranów, jak Józio w Ferdydurke sam przywołał profesora Pimkę, ogłaszając swój „Pamiętnik”. Nekrošius z pewnością uważnie przeczytał ten fragment pierwszego rozdziału powieści Gombrowicza:

Dlaczego, jak gdyby na przekór własnym zamierzeniom, książce dałem tytuł Pamiętnik z okresu dojrzewania? Próżno przyjaciele doradzali mi, abym nie dawał takiego tytułu i strzegł się w ogóle najdrobniejszej aluzji do niedojrzałości. - Nie rób tego - mówili - niedojrzałość drastyczne pojęcie, jeśli sam siebie uznasz niedojrzałym, któż cię dojrzałym uzna? Czyliż nie rozumiesz, że pierwszym warunkiem dojrzałości, bez którego ani, ani, jest - samemu uznać się dojrzałym? Lecz mnie się zdawało, że wprost nie wypada zbyt łatwo i tanio zbywać smarkacza w sobie, że Dorośli zbyt są bystrzy i wnikliwi, aby dali się oszukać, i że temu, kogo smarkacz ściga nieustannie, nie wolno ukazać się publicznie bez smarkacza. Za poważny może miałem stosunek do powagi, zanadto przeceniłem dorosłość dorosłych ${ }^{16}$.

Interpretacja Nekrošiusa bliska jest przenikliwej egzegezie Jana Błońskiego. Litewski reżyser nie czuł się jednak zobowiązany zaświadczać o tragiczności położenia Henryka, nawet w wymiarze psychologicznym, ani, jak Gombrowicz, windować go w hierarchii bohaterów do poziomu Hamleta czy Fausta... Nekrošius zdaje się nam mówić, że trudno traktować poważnie wielkie dylematy filozoficzne bohatera Ślubu, skoro są one formułowane $\mathrm{z}$ pozycji podmiotu, który sam siebie świadomie infantylizuje w pogoni za „ciemnymi” namiętnościami. Tym samym przeciwstawia się naczelnej koncepcji człowieka nowoczesnego, którą sformułował Gombrowicz, chętnie posługując się metaforą żeglugi morskiej:

16 W. Gombrowicz, Ferdydurke, [w:] idem, Dzieła, t. 2, red. J. Błoński, Kraków 1987, s. 8 . 
Ludzkość to statek, który na zawsze odbił od przystani, nie ma już portów ani kotwic, tylko nieskończenie płynny ocean pod niebem pozbawionym nieruchomej prawdy. Musimy przyzwyczaić się do tej samotności. Musimy nauczyć się żeglugi w tych mętach. Trzeba umieć płynąć i jeśli nie posiądziemy tej sztuki, zawsze będziemy wzdychać do jakiejś przystani ${ }^{17}$.

Koncepcja ta weszła do kanonu interpretacji dzieł Gombrowicza, została nie tylko przyjęta, ale i uwznioślona. Wyraźnie też zainspirowała samego Nekrošiusa, który świat wokół zdziecinniałego Henryka skonstruował na kształt statku, a jego lęk przed „zatonięciem” w odmętach, z jednej strony, pożądania, z drugiej - relatywizmu wyraził całą serią działań aktorskich, które jednakowoż przywodzą na myśl morskie przygody samego pisarza. Najbardziej spektakularne jest w spektaklu „topienie” Henryka przez rodziców. Uwagę zwraca jednak także moment, w którym Władzio rzuca przyjacielowi koło ratunkowe, wybawiając go z opresji. Władzio nie zdradza Henryka, to Henryk zdradza Władzia, i choć czyni to ze słabości, ciągle maskowana nielojalność i lęk stają się najważniejszymi pierwiastkami kondycji tego mężczyzny.

Ciekawe, że „pijany” swoją niedojrzałością Henryk zarzuca „pijaństwo” innym, przede wszystkim Pandulfowi, w którym słusznie - jako samozwańczy władca, a nawet Bóg - odnajduje swego największego przeciwnika. W dramacie Gombrowicza biskup jest postacią, która z wysokości swego urzędu rzuca klątwę na Henryka, ale nie jest w stanie przerwać jego „ciemnych” praktyk tyrana i bluźniercy. Inaczej w spektaklu litewskiego reżysera, który w roli Pandulfa obsadził piękną, wysoką kobietę o blond włosach. Magdalena Warzecha nosi długą pomarańczową suknię, zapinaną na kilkadziesiąt guzików, i miękkie ciżemki, w których jak duch porusza się po scenie. Aktorka pojawia się na niej tylko na początku trzeciego aktu, by powiedzieć Henrykowi, że Bóg jednak istnieje, a on jest wielkim uzurpatorem. Jej Pandulf stale towarzyszy bohaterom, jest milczącym świadkiem ich poczynań; zasmuconym, ale nie zrozpaczonym. Od czasu do czasu inicjuje

17 Rozmowa Karola Świeczewskiego z Witoldem Gombrowiczem przytoczona w: J. Giedroyc, W. Gombrowicz, Listy 1950-1969, Warszawa 2006, s. 483. 
też na scenie tajemnicze obrządki, które tak opisałem w mojej własnej recenzji spektaklu:

Kobiecy Pandulf ma swój własny obrządek i własne ceremonialne akcesoria: dwa szklane słoje i dwie pałeczki, które okazują się futerałem dla szarfy gimnastycznej. Wręcza je najpierw w akcie drugim Henrykowi i Mani niczym kwiaty w wazonie, potem zapala zapałkę i płomieniem omiata futerały. Nie podpala ich, raczej nasyca energią ognia, który jest znakiem tego niespokojnego ducha. Bohaterowie wstają z krzeseł, biorą do rąk futerały i nagle uwalniają szarfę (wtedy zresztą przekonujemy się, czym są te przedmioty). Taśma rozwija się spiralnie w dół, przypominając wartki strumień wody, której - w metaforycznym planie spektaklu - jakby nagle ubywa! Stojąc blisko narzeczonej, Henryk nie topi się w rodzicach, przez chwilę pozostaje od nich niezależny i wygląda na szczęśliwego. Młodzi z radości kreślą szarfą białe kręgi i jest to moment zachwycający. W przedstawieniu Nekrošiusa tylko ten zachwyt możemy przeciwstawić przerażeniu światem, który w trzecim akcie pogrąża się w sinym blasku śmierci ${ }^{18}$.

Nekrošius burleskowo obniżył styl dramatu Gombrowicza, nie litując się nad jego bohaterem. W tym błaznującym jak dziecko, groźnym i stale rozgrzeszanym ze swoich poczynań mężczyźnie (w ostatniej scenie spektaklu Matka z Ojcem kładą ręce na głowach Henryka i Władzia) łatwo dostrzec współczesnego trickstera - ironicznego niedojrzalca, infantylnego odmieńca, figurę dominującą w postmodernistycznym teatrze, nie tylko na scenie, ale i w życiu publicznym. Litewski reżyser poważnie zapytał o jej status i wartość, podważając największy z Gombrowiczowskich mitów - pielęgnowany do dziś mit niedojrzałości jako warunku rozwoju kultury i społeczeństw. Wprowadzając na scenę kobiecego, eterycznego, anielskiego Pandulfa, wziął też w metafizyczny nawias psychoanalityczną „tragedię" bohatera Ślubu. Oczywiście, w swoim ostatnim, jak się okazało, przedstawieniu „zdradził” Gombrowicza, ale była to zdrada twórcza, może nawet - wyzwalająca.

18 J. Kopciński, Dzieciak w mętnej wodzie, „Teatr” 2018, nr 7-8, s. 11. 


\section{Bibliografia}

Jacek Błoński, „Ślub” jako tragedia psychoanalityczna, [w:] idem, Forma, śmiech i rzeczy ostateczne. Studia o Gombrowiczu, Znak, Kraków 1994.

Jolanta Brach, O znakach literackich $i$ znakach teatralnych, [w:] Problemy teorii dramatu i teatru, red. J. Degler, Wydawnictwo UWr, Wrocław 1988.

Witold Gombrowicz, Ferdydurke, [w:] idem, Dzieła, t. 2, red. J. Błoński, Wydawnictwo Literackie, Kraków 1987.

Witold Gombrowicz, Kronos, Wydawnictwo Literackie, Kraków 2013.

Witold Gombrowicz, Ślub, [w:] idem, Dramaty, Wydawnictwo Literackie, Kraków 2012.

Witold Gombrowicz, Testament. Rozmowy z Dominikiem de Roux, tłum. I. Kania, Wydawnictwo Literackie, Kraków 2012.

Jacek Kopciński, Dzieciak w mętnej wodzie, „Teatr” 2018, nr 7-8.

Tadeusz Kowzan, Znak w teatrze, [w:] Problemy teorii dramatu i teatru, red. J. Degler,

Wydawnictwo Uniwersytetu Wrocławskiego, Wrocław 1988.

Klementyna Suchanow, Gombrowicz. Ja, Geniusz, Czarne, Wołowiec 2017.

Jerzy Giedroyc, Witold Gombrowicz, Listy 1950-1969, Czytelnik, Warszawa 2006. Jacek Wakar, Pustka marionetek, https://kultura.onet.pl/teatr/pustka-marionetek-slub-witolda-gombrowicza-rez-eimuntas-nekrosius-teatr-narodowy-w -recenzja/36q077c.

\section{Fanny-fication of Henryk, or Nekrošius Stages Gombrowicz}

The subject of the essay is the staging of Gombrowicz's Slub [The Marriage], directed by Eimuntas Nekrošius at the National Theatre in Warsaw, treated as an example of 'creative betrayal' of the stage arranger towards the author of the dramatic text. 'Creative betrayal' is a perfect metaphor for directorial interpretation, which consists not so much in the stage materialisation of the fictional universe of the drama, as in the translation of the literary work's meanings into the signs of a theatrical work. Referring to the theory of the spectacle as intersemiotic translation, the author shows how the stage world remains a creative reaction to the dramatic situations and conflicts designed by the playwright, as well as - to put it much more broadly - the image of a man and the shape of reality. According to the author of the essay, such a reaction as a rule contains polemic elements in relation to the playwright's vision. 
Nekrošius remains polemical towards Gombrowicz, but his criticism included in the actions of actors, scenography, costumes, and all directorial solutions - takes on a very deceitful shape. In his interpretation of The Marriage, the Lithuanian director focused on the motif and the problem of betrayal, which seems to be crucial in his worldview, based on psychoanalysis and existentialist philosophy. In this way, the stage arranger's 'betrayal' became only an ironic response to the author's 'betrayal', proving in fact 'faithfulness' to the meanings of the The Marriage, which was not noticed by the reviewers of the performance. Recalling the statements of one of them, author makes us aware of the complicated relationship between the author of a dramatic work, its director and the reviewer of the performance. And at the same time - of how typical for the dynamics of cultural life is the conflict between the participants of the artistic and critical dialogue.

Keywords: Ślub [The Marriage], Witold Gombrowicz, Eimuntas Nekrošius, theatre performance, 'creative betrayal' 